Marquette University

e-Publications@Marquette

English Faculty Research and Publications

English Department

$7-1-1978$

\title{
Oedipus Agonistes: Mothers and Sons in Richard Wright's Fiction
}

Diane Hoeveler

Marquette University, diane.hoeveler@marquette.edu

Published version. Black American Literature Forum, Vol. 12, No. 2 (Summer, 1978): 65-69.

Permalink. (C) 1978 St. Louis University. Used with permission. 


\title{
OEDIPUS AGONISTES: MOTHERS AND SONS IN RICHARD WRIGHT'S FICTION
}

\author{
DIANE LONG HOEVELER
}

A central problem in understanding Wright's fiction has been coming to grips with the violence, motivated or unmotivated, toward female characters. In "Alas, Poor Richard," James Baldwin observes that in black fiction "there is a great space where sex ought to be; and what usually fills this space is violence." Baldwin interprets the violence in Wright's fiction as "compulsive" and "gratuitous" because the source is never examined. But Baldwin suspects that the root of violence in Wright's fiction is the rage of a man being castrated, that is, "unmanned" by a white society. ${ }^{1}$ This essay endeavors to show, however, that the pervasive violence toward women in Wright's fiction is caused by the irreconcilable oedipal dilemmas that afflict his heroes.

With the publication of studies by Margolies and Brignano ${ }^{2}$ we have derived a fuller understanding of the Freudian dimensions in Wright's fiction. Neither of these studies, however, extends its perspective to the important mother-son relationship. Fabre's recent biography is more helpful for the personal dimensions behind the fiction. For instance, Fabre recounts Wright's intense interest in Freudian interpretations of violence as exemplified in Wright's involvement with Clinton Brewer, a young black man imprisoned for killing a woman. Wright introduced Brewer to Dr. Frederic Wertham, a Freudian psychoanalyst, who helped plead for Brewer's release. Wright and Wertham were successful; however, Brewer murdered another woman shortly after his release and this time Wright and Wertham had to marshal their energies to save Brewer from execution. ${ }^{3}$

Wright's interest in the Brewer case and his association with Wertham can be utilized to understand the general depiction of women in his fiction. That is, his increasingly self-conscious treatment of the Freudian theme centers on the relation to and influence of the mother. Significantly, women do not appear in Wright's fiction except as mothers or surrogatemother figures. Consequently, the hero is inevitably engaged in a fruitless quest for the mother's undivided loyalty. As Simone de Beauvoir has observed, "Since every woman is endowed with the general essence of Woman, therefore of the Mother, it is certain that the attitude held toward the Mother will have repercussions in a man's relations with wife and mistresses." 4 It is a pattern in Wright's heroes that they are both strongly attached to the motherimage and at the same time disillusioned by the corruption of what should have been her sexual inviolability. They are forced, then, into the position of accepting woman either as an asexual, pure being, or as a whore, soiled and deserving of death.
Fabre traces Wright's personal ambivalence and fear of women to the beating he received from his mother after he set a fire in their house. Richard, according to Fabre, regarded this punishment "as a betrayal. It not only seriously inhibited his independent spirit but also caused him to doubt his relationship to his mother. . . . This episode brutally shattered the emotional security he had derived from the exclusive affection of his mother." 5

Wright presents his version of this betrayal in his autobiography Black Boy. After the beating he describes himself as "lost in a fog of fear" so that whether he was awake or sleeping he was terrified of the "huge wobbly white bags, like the full udders of cows, suspended from the ceiling above me." Later, he becomes gripped "by the fear that they were going to fall and drench me with some horrible liquid." 6 Clearly the beating has caused the child to see the maternal breasts, not as nourishing, but as destructive. This is made explicit when Richard remarks that "for a long time I was chastened whenever I remembered that my mother had come close to killing me" (p. 6).

Without belaboring Wright's personal attitude toward his mother, I will suggest that Wright came to understand his own personal dilemma, projected into his writings, in terms of a self-conscious and increasingly deliberate Freudian perspective. In fact, one of Wright's last works, Savage Holiday, is virtually a textbook narrative of Freudian clichês, in contrast to the less theoretical and more powerful early works.

Wright's first novel, Lawd Today (1935-37), depicts the struggles of a black middle-class post office employee, Jake. Written in the day-in-the-life style, Lawd Today begins and ends with Jake's beating his wife. The marriage of Jake and Lil has become not only loveless, but sexless. Her incapacity for sexual relations, the result of a botched abortion which Jake engineered, places Lil in a maternal position. Jake assumes a child-like position toward her and is so jealous of her conversations with the milkman that he returns to the house to spy on her. His frustrated dependence on her culminates in the frequent and violent beatings that later in Wright's fiction become overt attempts at matricide. Like a mother, Lil attempts to discipline Jake, which she does through threatening his job.

Jake's efforts to retaliate against Lil take the form of attempts at gambling and adultery with prostitutes. Blanche, a black woman with an appropriately ironic name, dances with Jake so that her male accomplice can more easily pick his pocket. After this futile experience, Jake returns to Lil, who has spent the even- 
ing mourning and praying for her wayward husband/ son. The defeated Jake can soothe his frustrations only by beating her, so that the novel has come full-circle.

Whereas Lawd Today presents the sexual frustrations of a son-figure, "The Man Who Killed a Shadow," part of the collection entitled Eight Men, depicts the murder of a woman who exists only as a "shadow" to the black hero, Saul Saunders. To Saul, all people are shadows; however, women are particularly threatening. While working as a janitor, Saul is asked by a white librarian to clean under her desk. He finds her "sitting with her knees sprawled apart and her dress drawn halfway up her legs." 7 Saul becomes "baffled, humiliated, frightened, afraid to express his anger openly" (p. 201). When the librarian calls Saul a "black nigger," he slaps her and she begins to scream. In his attempts to silence the librarian, he flees to the roof, finds a pile of wood, and grabs a piece of "oaken firewood" as a weapon. After hitting her over the head and strangling her, he finally plunges a knife into her throat and uses her pink panties as "a good mop to clean up the blood" (p. 204).

The peculiar use of firewood as a weapon reminds the reader of Wright's biography of the Bibbs episode, which Wertham uncovered as an "unconscious determinant" in the composition of Native Son. ${ }^{8}$ Clearly the same situation exists in this short story. Again, the young black handyman is confronted suddenly with a partially-clad white woman in a potentially sexual situation. In the real life incident, Wright was bringing firewood to Mrs. Bibbs' bedroom. In the fictional version, the firewood (which is hardly a practical fuel source for a cathedral) becomes the weapon that the victimized black man turns on the threatening woman.

When discussing Wertham's findings, Wright verified the Bibbs episode as "the soil out of which Native Son came.'" 9 But Native Son, the classic work of Wright's career and a mid-point in his development, reveals more than Bigger's response to Mary and Mrs. Dalton as white women. Significantly, in "How 'Bigger' Was Born" Wright claimed that he wrote Native Son "to free myself of this sense of shame and fear." $10 \mathrm{He}$ also observes that he was forced to deal "with Bigger's dreams, his fleeting, momentary sensations, his yearnings, visions, his deep emotional responses" (p. xxiv). But rather than interpreting these emotions as purely a desire for improved social and racial conditions, it seems that Wright was aware of the deeper psychological currents represented by Bigger. He writes:

There seems to hover somewhere in that dark part of all our lives, in some more than in others, objectless, timeless, spaceless element of primal fear and dread, stemming, perhaps, from our birth (depending upon whether one's outlook is Freudian or non-Freudian!) a fear and dread which exercises an impelling influence upon our lives all out of proportion to its obscurity.

(P. xxv)

Only toward the conclusion of Native Son does Bigger feel "hate and shame and despair" when his mother and sister visit him in his prison cell (p. 276).
It would seem that this shame, then, constitutes the son's dependence on the mother. Bigger explains that "he had always acted hard and tough toward his mother" in order to conceal his frustration at being unable to support and please her. In Bigger's case, this shame and fear find their only outlet in unconscious and displaced matricide, for by killing Mary and Bessie, Bigger escapes, momentarily and vicariously, from the frustration of his oedipal dilemma.

Bigger is painfully aware of his mother's disappointment and repudiation (" "Bigger, sometimes I wonder why I birthed you' " [p. 11]), and upon arriving to work for the Daltons, Bigger quickly identifies Mrs. Dalton as a potential maternal figure whom he does not want to disappoint ("He had a feeling toward her that was akin to that which he held toward his mother" [p. 62]). But Bigger's attention is quickly diverted by the presence of Mary, to whom he evidences an ambivalent attitude. She is "beautiful, slender, with an air that made him feel that she did not hate him with the hate of other white people." But, he reminds himself, "she was white and he hated her" (p. 81). Mary, then, clearly embodies Bigger's fantasies about rich white women as sexual partners. But Mary's "accidental" murder hints strongly at displaced matricide, at least unconsciously. Until the blind Mrs. Dalton entered the room, Bigger's intentions were amorous rather than murderous. But when Mrs. Dalton enters the room Bigger is seized by "hysterical terror" so that he felt as if "he were falling from a great height in a dream" (p. 84). This dream-like atmosphere reinforces the notion that Bigger's actions are motivated less by his conscious mind than by his unconscious.

In his attempts to silence Mary's mumbling, Bigger accidentally smothers her, but on another level there is much more significance to his actions. As he later explains to Max, " 'I couldn't do nothing when I turned around and saw that woman [Mrs. Dalton] coming to that bed. Honest to God, I didn't know what I was doing.' " Yet when Max presses Bigger about whether he was conscious or not, Bigger replies, " "I knew what I was doing, all right. But I couldn't help it. That what I mean. It was like another man stepped inside of my skin and started acting for me' " (pp. 325-26). This "other man" who possesses Bigger is his unconscious which perceives Mrs. Dalton as a spectre of his own disapproving and castrating mother. It is Mrs. Dalton who is the awesome "white blur floating toward him" that intimidates "him to the core" (p. 85). Bigger's perception of Mrs. Dalton as a "white blur" reminds the reader of Black Boy of the threatening maternal udders that produce irrational fear in the hero. But this time the hero has a surrogate object on which he can avenge the maternal betrayal. After killing Mary, it is significant that Bigger feels as if "he had been in the grip of a weird spell and was now free" (p. 86).

But Bigger is not totally free of the maternal figures that surround him. His relationship with Bessie is also inadequate and fails to provide him with the emotional support he needs. She functions 
throughout their interactions as another female who uses her sexuality to make demands. Her role as a surrogate-mother is made clear when she warms milk for Bigger, and he promptly consumes three glasses after confessing Mary's murder. Bigger, of course, murders Bessie and goes to his execution convinced that neither Mary nor Bessie were "real to him, not human beings" (p. 108). Indeed, they were not human so much as they were substitute objects for the real target of the hero's rage, the mother. As Bigger assures Max, “'I ain't worried none about them women I killed. For a little while I was free. I was doing something. It was wrong, but I was feeling all right.' " He further declares that " 'What I killed for must've been good. . . . When a man kills, it's for something' " (pp. 328-29). Ironically, Bigger can find the only fulfillment in his life by destroying two women who accidentally find themselves identified with his mother.

The final work to be considered, Savage Holiday (1954), was written during Wright's Parisian exile and reflects the influence of Wertham's study of matricide, Dark Legend (1949). By this time in his career, Wright had read extensively in Freud so that, while the oedipal struggle and matricide had been previously displaced in his fiction, Savage Holiday, dedicated to Clinton Brewer, presents a blatant portrait of a destructive, promiscuous mother killed by a frustrated and betrayed son-figure.

An examination of Dark Legend reveals themes that Wright was to repeat in Savage Holiday. Wertham explains that the subject of his study, Gino, murdered his mother because of her affair with a man after the death of Gino's father. In Savage Holiday, Wright's hero Erskine kills Mabel Blake because of her promiscuity after her husband's death. The significant aspect of both men's attitudes toward their mothers or surrogate-mothers is the frustrated worship that both feel rightly belongs to a proper mother. Gino remarked after his crime, " 'If she was honest, I would not kill her. I would kiss her feet. If she was a good mother I would do anything for her." " 11 As Wertham notes, Gino killed his mother "not in spite of his love for her, but because of it." 12

In an identical fashion, Savage Holiday concerns the son's hatred of the promiscuous mother. From Erskine's first action, his compulsive handling of the four colored pens in his pocket, we begin to be aware of a man who is emotionally damaged. By constantly touching the pens, Erskine keeps in contact "with some emotional resolution whose meaning and content he did not know." 13 We are also presented with a man who is so potentially dangerous that he admits "he had to encircle himself, his heart, and his actions with bars, to hold himself in leash" (p. 34). Erskine's rage, like Gino's, stems from his memory of his mother's betrayal. As a child sick with a fever, Erskine was left alone when his mother went out with a man. He broods over this incident and remembers "hating her, trying to think of the many things he wanted to do to her to make her feel it" (p. 39). Mrs. Fowler's desertion of Erskine is reminiscent of Ella Wright's severe beating of Richard, as well as the time she turned Richard and his brother over to an orphanage.

In order to understand how heavy-handed Wright's fictional treatment of the oedipal dilemma is in Savage Holiday, we must refer to Freud's essay "A Special Type of Object Choice Made by Men." In describing men afflicted with the oedipal fixation, Freud observes that these men feel passion only when jealous instincts intervene. This type of man also thrives on a desire to "rescue" the beloved because he sets a high value on her promiscuity. Finally, the man suffering from an oedipal complex wishes to show his gratitude toward his mother "by wishing to have a son by his mother that shall be like himself." In effect, the only way the son can identify with the father is to literally desire "to be the father of himself." 14

Wright presents a fictional version of this desire to be the father of oneself in the extremely heavy-handed depiction of Erskine's relationship with Tony. On the literal level, Tony is Mabel's son, but he is also an earlier version of Erskine with whom Erskine identifies. Mabel makes this explicit by saying, "You reminded me so much of Tony. . . . You need a mother" (p. 183). The irony of this statement is lost because the relationships are simplistically clichéd.

Another Freudian theme, the child's witnessing of the primal scene, is utilized in Savage Holiday, as it was in almost all of Wright's earlier work. In "Infantile Sexuality" Freud observes that children who witness sexual intercourse between their parents imagine that they are participating in an act of subjugation or sadism. ${ }^{15}$ In a textbook-like manner, Tony tells Erskine that he has seen his mother "fighting" with men and declares that he does not want to grow up because " 'I don't wanna fight ladies like my mother'" (p. 99).

Finally, in "The Most Prevalent Form of Degradation in Erotic Life," Freud explores the necessity of unifying the tender, affectionate feelings with the sensual in order to ensure a fully normal attitude in love. But for men who have not passed beyond the oedipal stage, there is no tenderness for the sexual object. Instead, "as soon as the sexual object fulfills the condition of being degraded, sensual feeling can have free play." Typical in this type of man is the fantasy of imagining the mother as a prostitute so that "by degrading her, he can win the mother as an object for sensual desire." 16

Again, in a wooden fashion Erskine needs to picture Mabel as so degraded that he can "save her, rescue her" (p. 127). He imagines their marriage in hopelessly naive terms: "She'd obey him! she was simple; and above all, he'd be the boss; he'd dominate her completely" (p. 134). Only after "conquering" and "humbling" Mabel can Erskine "be compassionate, loving toward her"' (p. 160). Although he tells her that she is "haunting him," it is clear that it is the memory of his mother that is haunting him. After proposing to Mabel, Erskine feels "wrapped in the fulfillment of a long-sought dream," that is, the dream of an incestuous relation with the mother (p. 165).

But very quickly Erskine's extreme jealousy makes 
him realize that marriage to Mabel would be impossible, for he would be always plagued by anxiety over her fidelity. In his letter to her he ironically states his own recognition of her resemblance to his mother: "This entire thing is a foolish case of mistaken identity and, if we let it continue, it will only mean misery for both of us' (p. 185). The final confrontation occurs and Erskine is allowed the vicarious pleasure of condemning his own mother's misbehavior through Mabel. He attacks her as "so careless, so stupid, so inhuman, so brutal that you thought that a child could look right at such as that without its influencing him. It was just a picture of violence. . . . you crushed that child; you killed him" (p. 200). Although a moment of reconciliation occurs, Mabel qualifies her pledge of fidelity with the fatal "If." That is, she cannot pledge absolute faithfulness and that qualification makes Erskine feel "abandoned, naked lost."

Erskine's murder of Mabel is strikingly similar to Gino's murder of his mother in Wertham's Dark Legend. Both heroes explode in classic oedipal frustration, while Erskine, when he learns from Tony of Mabel's affairs, rages: "Women oughtn't to do things like that" (p. 105). Both books and traditional Freudian theory claim that mothers should be pure objects worthy of the worship of their sons. When mothers are instead promiscuous, they force their sons out of the role of worshipper at the shrine to competitor for the mother's sexual favors. The end result of that attempt can only be frustration, castration, and anger. Significantly, the real-life Gino used a kitchen butcher knife to kill his mother and that device is echoed in Wright's fictional version when Erskine attacks Mabel's "nude stomach with machinelike motion." The phallic associations are again and unfortunately rather too manifest.

Savage Holiday is not a work that Wright critics have been particularly fond of discussing and it is obviously a much weaker work than either Lawd Today or Native Son. But Savage Holiday is not a fluke in Wright's career, for it utilizes themes that are dominant throughout Wright's work. Unfortunately, the Freudian themes have become simplistic clichés employed with little or no art. In fact, one senses that the characters are developed to further the pat and preconceived plot. The question remains, however, why did Wright compose and insist on the publication of Savage Holiday? One can claim that he lost his artistic power when removed from his American and Black roots or one can, like Robert Bone, claim that Wright's decline was caused by "his inner life." That is, Wright's personal rebellions were rooted in "his relations with his mother. . . . To rebel against maternal authority is to establish a sense of self, but also to risk abandonment, the loss of mother love." According to Bone, Wright "embraces demonism and its consequence, abandonment. As a result, his art dries up." 17

Wright makes the connection between mother love and his work as an artist explicit when after the murder Erskine is reminded of "killing" a drawing of a playmate's doll, an act that he now understands as a substitute killing of his mother. He realizes that the surrogate murder was a daydream that he had experienced while drawing with colored pencils, making clear his lifelong need to keep in touch with the pens in his pocket. In a symbolic extension, the reader of Wright's fiction can see a parallel between Erskine's need to fondle those pens and Wright's work as an artist. He, too, has kept in touch with the emotional trauma made acute by his attitude (justified or not) toward his mother. But ultimately this personal source is artistically barren. The son's rebellion is meaningless and sterile and this is what Wright demonstrates in Savage Holiday, albeit inadvertently. In his autobiography Chester Himes humorously recalls that "Dick told us that the plot for Savage Holiday had come to him suddenly several months previously when he had been in bed with a high fever. Later, when he had let me read the finished manuscript, I believed him." 18 The reader of Wright's earlier fiction is tempted to laugh at or dismiss Savage Holiday, but in its graphic depiction of a man caught in the tangle of his ambivalent emotional responses to a maternal figure, Wright concludes his treatment of a theme that had preoccupied his imagination for over twenty years.

\section{NOTES}

1 “Alas, Poor Richard," in Nobody Knows My Name (New York: Dial, 1961), pp. 187-88.

2 See particularly Edward Margolies, The Art of Richard Wright (Carbondale: Southern Illinois Univ. Press, 1969), chapters eight and nine; Russell C. Brignano, Richard Wright (Pittsburgh: Univ. of Pittsburgh Press, 1970), chapter four.

3 Michel Fabre, The Unfinished Quest of Richard Wright, trans. Isabel Barzun (New York: Morrow, 1973), pp. 236-37.

4 The Second Sex, trans. H. M. Parshley (New York: Knopf, 1970), p. 184.

5 Fabre, p. 10.

6 Richard Wright, Black Boy (New York: Harper, 1945), p. 6. All quotations from Black Boy will be from this edition with page numbers in parentheses.

7 "The Man Who Killed a Shadow," in Eight Men (Cleveland: World, 1961), p. 200. All quotations will be from this edition with page numbers in parentheses.

8 Frederic Wertham, "An Unconscious Determinant in Native Son," Journal of Clinical Psychotherapy, 6 (1944), 111-15.

9 Ibid, p. 113.

10 Native Son (1940; rpt. New York: Harper, 1966), p. xxii. All quotations from "How 'Bigger' Was Born" and Native Son will be from this edition with page numbers in parentheses.

11 Frederic Wertham, Dark Legend (New York: Doubleday, 1949), p. 121.

12 Ibid., p. 190

13 Savage Holiday (New York: Award, 1965), p. 21. All quotations will be from this edition with page numbers in parentheses.

14 "A Special Type of Object Choice Made by Men," in Freud: Sexuality and the Psychology of Love, ed. Philip Rieff (New York: Crowell-Collier, 1970), pp. 51, 52, 57.

15 "Infantile Sexuality," in The Complete Psychological Works (London: Hogarth, 1964), VII, 196.

16 "The Most Prevalent Form of Degradation in Erotic Life," in Freud: Sexuality and the Psychology of Love, pp. 59, 63.

17 Richard Wright (Minneapolis: Univ. of Minnesota Press, 1969), pp. 45-46.

18 The Quality of Hurt: The Autobiography of Chester Himes (New York: Doubleday, 1972), pp. 190-91. 